\title{
TRE DONNE SOLE: \\ PAVESE'S WOMEN IN SEARCH OF A MODERN IDENTITY
}

\section{STACY GIUfRE}

\begin{abstract}
Summary: "Tre Donne Sole: Pavese's Women in Search of a Modern Identity" analyzes the representation of women in three of Cesare Pavese's works: "Pensieri di Dina," La bella estate, and Tra donne sole. This article argues that the depiction of women and gender in these texts is more modern and complex than one might originally suspect considering Pavese's reputation as a misogynist and the essentialist claims that appear throughout his work.
\end{abstract}

As Simone de Beauvoir famously declared in The Second Sex, "One is not born a woman, but one becomes one" (267). At first glance, De Beauvoir, one of the greatest feminist theorists of the twentieth century, and Cesare Pavese, often characterized as a misogynist author, may not seem to have much in common other than their common year of birth, 1908. However, the representation of women and gender in Pavese's work is more modern and complex than one might originally suspect despite the essentialist claims that appear throughout his work such as "Adulti o Bambini si nasce, non si diventa" (MDV 10/20/1940). The depiction of three Pavesian women-Dina, Ginia, and Clelia-contradicts the fixed notion of identity or essence that Pavese affirms in his diary. In "Pensieri di Dina," La bella estate, and Tra donne sole, woman is not simply an adult female human being, but she also becomes an adolescent boy and a modern rebel neither defined nor limited by biology. In these texts, the narrators and the women themselves seem to intuit, as Judith Butler observes, that "if there is as it were, a compulsion to repeat, repetition never fully accomplishes identity" (24). These three women undergo a process of becoming, of constituting and reconstituting their identities, through the various performances with which they present themselves to the world.

Some of Pavese's most liberated protagonists are the prostitutes who appear in "Pensieri di Deola" (1932), "Pensieri di Dina" (1933), "Agonia" (1933), and "Ritorno di Deola" (1936). ${ }^{1}$ Dina, however, best exemplifies

${ }^{1}$ In "La pregnante vanita di Colei ha non ha posto," Jacqueline Spaccini discusses the differences between "Pensieri di Deola" and "Ritorno di Deola." Though 
how women outperform cultural expectations and limits. Though "Pensieri di Dina" sets up a series of binary oppositions - city and country, man and woman, work and leisure-these oppositions, as well as gender roles and stereotypes, come undone as the poem progresses; the representation of gender and the narrative voice are slippery. Though the poem is entitled "Pensieri di Dina," which implies that someone else is recounting Dina's thoughts, the first few lines create a transition between the title and the body of the poem, in which Dina speaks with her own voice. In the first stanza, the narrator uses the si impersonale to describe the universal pleasure that derives from diving into dark, cold water and re-emerging into the sunlight to see the world with "occhi lavati" (7). In the second stanza, however, it is as though the river has washed away the remnants of the impersonal and external narrator that had previously watched from above. Here, Dina describes herself with the gender-specific adjective "nuda" and establishes her voice as she says, "mi ha visto tuffarmi" $(8,12)$. Dina derives transgressive pleasure from communicating with her own voice-which is colloquial and far from the lyric voice of the Italian tradition-and from revealing her body as she thinks of the masses who look at the river without realizing that she is sunbathing nude. The pleasure her body provides is fueled by her desire to outwit the impersonal power that "questions, monitors, watches, spies, palpates, and brings to light" and the men who pay to derive pleasure from her body at night (Foucault 45). Paradoxically, though Dina's body is on display, she remains invisible.

Dina's invisibility is not inconsequential; it is a form of rebellion, especially considering her profession. As is well known, during Mussolini's regime, there was a move to control and make transparent women's bodies. As Victoria de Grazia observes in How Fascism Ruled Women, only one year after Mussolini rose to power in 1922, he began to legislate sexuality by requiring all prostitutes to carry a special passport that recorded the results of their gynecological examinations. Furthermore, by the mid-

Spaccini correctly notes the less hopeful, more disillusioned tone of the second poem, she collapses the text and undercuts the power of the woman's voice by identifying the female narrator as a stand-in for Pavese. She writes, "Nella poesia del '32, Pavese può ancora spacciare per altrui i pensieri negativi o persino edulcorarli. Il testo del '36 è non solo troppo autobiografico, ma che troppo smaccatamente specchio dissolutorio. Vuole essere un poeta costruttivo, lui, non uno che si piange addosso" (55-56). While Pavese, as author, leaves traces of his experience and of himself in these poems, a reading that views these texts as "infingimenti travestitori di Pavese" ignores their striking modernity and their liberating portrayal of women (Spaccini 56). 
1920s, new public security laws enabled local police to crack down on unregulated prostitution and to drive prostitutes into jails or state-regulated case chiuse, where doctors and police made the most private aspects of women's lives part of the public domain. Not only were women required to submit to obligatory medical check-ups and police surveillance, but they were also punished with "vexatious laws that imposed a six-month prison term for soliciting from the windows" of a brothel (de Grazia 44-45). Through laws and public information campaigns, government officials not only tried to draw a line between good women who serve the state as wives and mothers and bad women who must be hidden, but they also attempted to render visible and legible aspects of women's sexuality that were previously considered private. Considering this political climate, the simple pleasure Dina takes in displaying her naked body in a public space can be read as an act of defiance. Remarking on her potential spectators' blindness, Dina notes, "nessuno di là se ne accorge" (11). Her flagrant disregard for prevailing social and political norms goes unnoticed beneath the eyes of those who look without seeing.

Operating outside of the conventions that regulate acceptable behavior, Dina enjoys a liberating invisibility and maintains her freedom despite repeated encounters with objectifying others. Dina recounts how she can convincingly appear as an adolescent boy:

\section{[...] Quel vecchio in mutande}

e cappello, che andava a pescare, mi ha vista tuffarmi,

ma ha creduto che fossi un ragazzo e nemmeno ha parlato (11-13).

In her leisure time, Dina plays at being a boy who swims and sunbathes nude, and her performance is so successful that an old man who sees without comprehending does not suspect that she is a woman, or plays at being one for money. As Dina juxtaposes her current nakedness with the red dress she will put on that evening to attract customers, she suggests that her sex does not make her a woman. She writes:

Questa sera ritorno una donna nell'abito rosso

- non lo sanno che sono ora stesa qui nuda quegli uomini

che mi fanno i sorrisi per strada - ritorno vestita

a pigliare sorrisi. Non sanno quegli uomini

che stasera avrò fianchi più forti, nell'abito rosso, e sarò un'altra donna (14-19).

It is the "abito rosso" that attracts the smiles of the men who are interested in sex; Dina is not born a woman, but she continually uses her body 
and her clothing to become a series of different women. ${ }^{2}$ Dina's description of the performances that construct and deconstruct gender and identity, written fifteen years before the publication of de Beauvoir's The Second Sex, is surprisingly modern and progressive, especially considering that it appears in a text written by a man who has often been written off as a misogynist author.

Though Dina enjoys her intellectual superiority over the blind men ("sciocchi") who desire her when she puts on her red dress, she also expresses the utopian dream that these men would realize that her clothing does not define and contain her and that she is, in fact, "come loro" (24-25). Towards the end of the poem, Dina expresses her ideal in the conditional, writing, "Questa sera dovremmo poter star nudi e vederci / senza fare sorrisi da furbi" (29-30). Though, as we have seen, Dina derives pleasure from the men's blindness, she would prefer to be able to see and to be seen. Dina, who realizes the unrealistic nature of this dream, creates her own pleasure instead of relying on others or waiting for a moment of transcendence. She takes control of her own sexuality and learns to pleasure herself. She explains, "So farmi carezze da me" (28). Though the men who see Dina may think they can read her body and its accoutrements, they are blind to the secret pleasure she derives from slipping between roles, showing off, resisting, and exercising her body's performative potential. "Pensieri di Dina" does not narrate the story of a woman who is defined or contained by stereotypical identity or labels. Instead, Dina recounts the story of how she continually refashions sexuality and identity.

While Dina is an exceptionally modern woman for her time because she eschews social conventions, defies authorities, and understands the fluidity of sexual identity, La bella estate's Ginia is an ambiguous figure poised on the brink of maturity. Though Ginia is still a child at the beginning of the narrative, she is about to make the sexual discoveries that will launch her into adulthood. Noting the pivotal moment in which the narrative begins, feminist critic Francesca Gibson argues that Ginia's story is a Bildungsroman that recounts a modern heroine's journey towards maturity. Gibson claims, "[Ginia is] not just one of Western literature's long line of spurned mistresses_La bella estate is also a Bildungsroman, her Bildungsroman (for she is about seventeen) and she is just as much a wanderer as Pavese's male protagonists" (74). Gibson points out that though

2 For an insightful discussion of the importance of clothing in Pavese's work, see Rossella Riccobono's article, "Vestirsi, svestirsi, travestirsi: arte e gioco della voce pavesiana." 
Ginia's voyage of discovery takes place entirely in Turin, she is a mobile protagonist and is not constrained by marriage or domestic responsibilities. Though Gibson notices many of the ways in which Ginia is a modern and progressive character, she does not question the utility of using the term Bildung to define a woman's journey. As Flora Bassanese asserts in "Una donna: Autobiography as Exemplary Text," many novels about female maturation offer "models for 'growing down' instead of 'growing up' and fail to question whether male-defined maturity is a valuable goal in a patriarchal society that privileges marriage, self-sacrifice, and service to the State (135). ${ }^{3}$ While Ginia is initially presented as a self-sufficient character, her psychological voyage into uncharted territory leads her into darkness, dependence, and vulnerability rather than towards self-discovery and maturity.

Furthermore, as Franco Moretti asserts in Il romanzo di formazione, by the time Pavese wrote La bella estate, well after the Great War, the Bildungsroman was no longer a viable literary genre; consequently, Ginia's ego is not only marked by the collective trauma that rang the death knell of the Bildungsroman after World War I, but it also suffers from the unresolvable trauma of sexual awakening. In this novel, the narrative structure and the narrator's tone and voice seem to suggest that becoming an adult is an alienating and traumatic process. At the inception of Ginia's journey, the narrator implicitly compares Ginia to her friends to represent the detachment that insulates her from the world. Though the narrator is dialogic from the start, in the novel's opening passages, the narrator identifies with Ginia and sees the world largely with her eyes. For example, the narrator explains why Ginia feels special at sixteen:

Scherzava, Ginia - perché il suo piacere era proprio di starsene quell'ora in casa da sola, come una padrona -, ma a Rosa bisognava di tanto in tanto far capire che non erano più bambine. Neanche per strada Rosa sapeva stare [...]. In quell'anno così bello, che cominciavano a vivere da sole, Ginia s'era presto accorta che la sua differenza dalle altre era di essere sola anche in casa - Severino non contava - e di potere a sedici anni vivere come una donna (4-5).

3 Maturity is an ambiguous term in Pavese's work. While the epigraph for La luna e i falò reads "Ripeness is all," Pavese and his narrators do not define ripeness within the narrow constraints of bourgeois society. Pavese's most positive characters eschew marriage, parenthood, political commitment, and socially-sanctioned occupations. 
Here, Ginia is a truly modern heroine, constrained neither by a father figure, nor by a conservative mother, nor by the repressive politics of Fascism that sought to limit women's presence in the workforce. What makes Ginia's life on the brink of maturity so wonderful ("così bello") is not her relationship with others, but her ability to be by herself and to determine how she spends her days. Maturity, then, does not bring the happiness that the protagonist of the traditional Bildung attains at the end of the narrative. Instead, the moment before maturity is attained constitutes the happy interlude, in which the protagonist is both "come una padrona" and "come una donna." Beauty and pleasure lie in the process of becoming, in the present progressive as opposed to the past perfect, which implies a certain crystallization and a closing off of possibilities.

Ginia's provisional happiness seems to hinge on her ignorance of sex and her ability to be alone. As Ginia becomes more sexually aware, however, the fragile utopia she inhabits begins to crumble. While Ginia's precocious friend Rosa is la stupida at the beginning of the novel, as questions of sex, transgression, and forbidden knowledge become more pervasive in the narrative, the epithets stupida and scema begin to rub off on Ginia. For example, when Rosa tells Ginia that she might be pregnant, Ginia realizes that she was "stupida" to think that what Pino and Rosa were doing in the woods was innocent (6). Though Ginia reminds herself that she is not as stupid as Rosa, by the end of the first chapter the narrator describes Ginia as "scema" because she had imagined that her friends were playing hide and seek in the fields (6). The narrator's choice of the words "scema" and "stupida" in these opening paragraphs is not at all casual. In the next 16 chapters that recount Ginia's journey, words like "padrona" and "donna" are no longer used to describe her. Instead, the narrator, other characters, and Ginia herself use terms such as scema, stupida, bambina, umiliata, ridicola, and sciocca at least thirty-six times to describe her. Though this use of demeaning modifiers could be a mark of linguistic realism, it could also be a semantic indicator of Ginia's journey away from self-sufficiency and towards her dependence on Amelia, who will become her mentor/tormentor.

As Ginia tries to figure out what it means to be a woman instead of "come una donna," she gradually relinquishes her power of self-determination and looks to Amelia for guidance, despite her reservations about Amelia's clothes, including her lack of proper stockings and a hat. Because life with Amelia and her artist friends is fast-paced and seductive, Ginia does not realize that she plays the role of the fool despite her brother's warning, "Sta' attenta [...] Amelia è in gamba, e tu con lei fai la parte della stupida" (43). Ginia’s movement away from independence and happiness 
accelerates when she asks to watch Amelia model:

Ginia disse che voleva vedere il pittore dipingerla: non aveva mai visto maneggiare i colori e doveva essere bello. "Non è per oggi né per domani," diceva "adesso sei senza lavoro. Ma se torni da qualche pittore, mi devi promettere che conduci anche me." Amelia rise un'altra volta e le disse che, quanto ai pittori, era il meno: sapeva dove stavano e poteva condurcela. "Ma sono carogna, sta' attenta." Anche Ginia rideva (12).

This passage contains a key to the novel's development and the suggestion of what is to come. Here, the verb condurre marks the start of a journey that ends on the last page of the novel when Ginia says to Amelia, "Andiamo dove vuoi [...] Conducimi tu" (89). While Gian-Paolo Biasin argues that the relationship between Amelia and Ginia is characterized by domination, violence, and attraction rather than instruction and improvement, their relationship is ambiguous. ${ }^{4}$ Mixing malevolence, friendship, and desire, Amelia both warns Ginia to be careful around painters and encourages her to disrobe for them. Amelia, who will usher Ginia into adulthood and arrange the end of her bella estate, is temptress and advisor, champion and rival.

Amelia's profession not only brings admiration and desire, but it also entails a problematization of sexuality and a struggle for mastery. When Amelia takes Ginia to meet Barbetta, Amelia's conversation with him hints at the relationship between posing, sexuality, and objectification:

"Scommetto che va a tradirmi con un'altra modella." "Con tutto il
mondo ti tradisco," gridò il pittore, chino a terra. "Credi di valere più di
una pianta o di un cavallo? Io lavoro anche quando passeggio, cosa
credi?" e intanto rovistava in una cassa sotto il cavalletto e buttava in aria
dei fogli, delle scatole, dei pennelli. Amelia saltò dalla sedia, si tolse il
cappello, e ammiccò a Ginia. "Perché non fa uno schizzo alla mia amica?"
disse ridendo. "Non ha mai posato per nessuno" (17).

Ignoring the signs that Barbetta enacts misogynist violence on Amelia's body, Ginia allows him to sketch her profile. Though Amelia warns Ginia,

${ }^{4}$ In The Smile of the Gods, Biasin observes "[...] the relationship is between the two girls [...] is not so much one of friendship as of subordination and attraction, unconscious on the part of Ginia, who is still an adolescent and inexperienced in comparison with Amelia, who is already an adult with a little too much experience: a relationship we have already seen in other Pavese characters and that is here described in a passage revealing the mediation resulting from the dialectic of master and slave" (93). 
"Se non ti muovi ogni tanto, lui si dimentica che posi e ti tratta come una serva," Ginia does not heed her more experienced friend's advice (12). Unable to see that the relationship between artist and model does not reproduce the exclusive (at least in name) and proprietary rites of traditional bourgeois courtship, Ginia allows Amelia's artists to determine how she appears to herself and to the world. As the female body, along with its reproductions and its progressive unveiling, becomes one of La bella estate's protagonists, Ginia loses control of her process of becoming and, unlike Dina, encourages others to define and objectify her.

As Ginia's fascination with the art scene intensifies, she becomes increasingly blind to the signs that she is flirting with danger. The narrator describes Ginia's thoughts as she contemplates Barbetta's work:

Nutriva un filo di speranza di farsi regalare le sue facce, non tanto per averle quanto perché non restassero esposte, là in mezzo, alla curiosità di chiunque. Non si capacitava che proprio Barbetta, quel vecchio papalotto grasso, avesse disegnato cancellato pasticciato le gambe la schiena il ventre i capezzoli di Amelia. Non osava guardarla in faccia. Quegli occhi grigi e quel lapis l'avevano fissata, misurata e frugata, più sfacciati di uno specchio, e lei ferma o magari a fare le capriole o discorrere (19).

Ginia's trepidation reflects her anxiety about the dismembering effect of Barbetta's art, which communicates the modernist tendency to dissect, abstract, and stylize the female form. Erring and erasing, Barbetta immobilizes, measures, and violates Amelia's body. While Amelia—older, rebellious, and resourceful-embraces the decentralizing and disruptive effect of Barbetta's modernist art, Ginia clings to traditional conceptions of art, identity, and love. Mourning the loss of a coherent, rational, and autonomous subjectivity, Ginia struggles to reconcile her antiquated and idealistic fantasies with the disruptive realities she witnesses in Amelia's world.

Ginia's sense of dislocation mirrors a historical reality that affected young urban women in Fascist Italy.5 In a society that both embraced

5 In "Rappresentazioni di sé e l'affiorare di una coscienza di classe in La bella estate," Rossella Riccobono astutely observes, "È chiaro che Ginia [...] si considera socialmente superiore alle persone che le stanno attorno (Rosa, Amelia, Guido) e rivela fin da subito un'ambizione di stampo prettamente capitalistico [...]. Gli oggetti da lei ritenuti importanti per potersi sentire presentabile, attraente, donna, e superiore socialmente sono oggetti che possono fare di una ragazzina una donna, di un'operaia una signora, di un maschio un travestito: abiti, cappelli con velette, calze di seta, vestiti, tutti simboli della classe borghese, sintomo anche sociale della trasformazione della società italiana da agricola in una borghese pre miracolo economico [...]" (128). 
modernity and clung to conservative visions of family and women's roles, cosmopolitan women like Ginia had access to American and French cultural products that promoted new images of women as independent, flirtatious, working, and modern, while government restrictions and incentives also encouraged them to find satisfaction as wives and mothers. Because of Ginia's marginal position-between old world values and new world desires and freedoms - she experiences a disorienting inability to decipher not only the phenomena she observes but also her own emotions. For example, the narrator describes the strange appearance of Amelia's body in Ginia's room:

Rivedeva nel buio il ventre nero di Amelia e quella faccia indifferente e le mammelle che pendevano. Non c'era forse di più da dipingere in una donna vestita? Se i pittori le volevano fare nude, dovevano avere altri scopi. Perché non copiavano uomini? Persino Amelia, svergognandosi in quel modo, diventava un'altra. Ginia quasi piangeva (21).

Ginia, like Dina, intuits that the decision to appear nude engenders ontological consequences; by disrobing, Amelia "diventava un'altra." Though Amelia remains "indifferente" during her transformation, Gina "quasi piangeva" and is traumatized by the ease with which Amelia transforms/is transformed. While Dina's nudity allowed her to avoid being reduced to a commodity, this is not the case for Amelia. It is not entirely clear how much agency, if any, Amelia retains as she allows her naked body to be copied, modified, and altered. While Dina's nudity rendered her invisible, Amelia's nudity seems to allow the painter to ignore the way in which Amelia would choose to present herself to the world and to re-envision her identity. While Amelia is not the master of her process of becoming, her appearance in the text does argue against an essentialist conception of identity. Through her own efforts (removing and putting on clothing) and her work as a model, Amelia continually remakes herself and is remade. Though Amelia and Ginia-through her association with Amelia-are exposed to danger, they are also portrayed as modern women with choices and substantial freedom to decide which path they will follow. There is no transcendental signified; a woman's body and its clothing or lack thereof have the potential to refashion her identity, for better or for worse.

Watching Amelia expose herself to the male gaze and perhaps intuiting her own fate, Ginia says, "Sembra di essere al cinema" (30). By disassociating herself from the role she plays and from the other actors in her drama, Ginia blurs the boundaries between engagement and estrangement, fantasy and reality. Both fascinated and frightened by Amelia's transgressive 
lifestyle, Ginia attempts to marginalize her connection to Amelia by establishing a relationship with Guido, another painter. In Guido's studio, which contains a red velvet curtain that cordons off his bed and "[arrossa] tutta la stanza," Ginia loses her virginity (37). The red-tinged room not only suggests the violence associated with sex acts, but it also evokes prostitution's red lights to indicate the exploitative nature of Ginia and Guido's encounter. Though Ginia hopes that losing her virginity will transform her, she is disappointed when she disrobes in front of her mirror. Instead of finding that sex has made her into a different woman, "si trovò sempre la stessa e le parve impossibile. Si sentiva la pelle come staccata dal corpo e ancora un resto di brividi freschi la correvano. Ma non era cambiata, era pallida e bianca come sempre" (61). Ginia ignores the body's ability to transcend trauma and reconfigure identity and allegiances. Though sex does not alter Ginia physically, she continues to believe-despite significant evidence to the contrary-that sex creates a sacred contract between one man and one woman. Still clinging to fairy tale visions of sex and relationships, Ginia thinks, "Nessuna donna, nessuna ragazza, poteva aver visto un uomo nudo come lei vedeva Guido. Una cosa simile non può succedere due volte" and decides that her real life has started now that she and Guido have seen each other naked (77).

Gina's new relationship with Guido, however, does not distance her from Amelia or from the dangerous aspects of sexuality that previously frightened her. When Ginia falls in love with Guido, not only does Amelia declare her love for Ginia — "Sono innamorata di te"—but she also reveals her sexual desire and her illness, admitting, "non ti posso dare un bacio. Ho la sifilide" (65). While Amelia declares herself "innamorata," it is not clear how she defines love since she asks Ginia to kiss the sore on her breast and sets Ginia up to be humiliated in a parody of a rite of passage that transforms Ginia's modeling debut into a traumatic event. When Ginia finally decides to disrobe in Guido's studio, she becomes not a muse but the star of a sideshow that binds the four protagonists together in a modern reinterpretation of a sacrificial rite in which Ginia appropriates the role of the victim.

Though Ginia's objectification and disillusionment end the bella estate of her youth, her unhappy ending conveys an ambiguous message. The sheer number of options Ginia has evidences her remarkable modernity; as a liminal character, Ginia comes to perceive possibilities for independent and alternative lifestyles. Reflecting the crisis that affects visions of marriage, gender, and sex in the twentieth century, Ginia both yearns for and mourns the loss of the Prince Charming fantasy and enjoys the freedom that economic independence and the advent of mass culture brought to some, 
mostly cosmopolitan, women in Italy. While Ginia's last words to Amelia, "conducimi tu," are ominous, they also reflect a choice to resist the pressure to marry and to live a conventional lifestyle as a wife and mother. ${ }^{6}$ Though Ginia and Amelia do not have the tools to conceptualize a female solidarity that not only flouts patriarchal expectations of women but also creates relationships that foster cooperation and creativity, they, nonetheless, can be seen as precursors to Thelma and Louise who make their way in a world of crumbling illusions. ${ }^{7}$

Though Gian-Paolo Biasin has read Clelia of Tra donne sole as a "grown up Ginia," Clelia did not follow another woman but fearlessly forged her own path (101). Far from a traditional female figure, Clelia challenges prevailing ideas about love, maternity, work, and sex. Again in Tra donne sole, a traumatic event involving the female body plays a pivotal role in determining conceptions of identity and articulations of desire. Soon after Clelia settles in at her hotel, Rosetta's lifeless body appears and disrupts Clelia's self-contained routine. When Clelia's maid fails to bring her tea because she is mesmerized by the spectacle of Rosetta's body lying on a stretcher in the hallway, Clelia surprises herself with an uncharacteristic reaction. She explains, "Feci una cosa che non avevo mai fatto, come se fossi una ragazza sciocca. M'infilai la vestaglia e socchiusi la porta" (231). Especially for Clelia, who chooses her outer-garments carefully, her decision to open the door while wearing a bathrobe signals her involuntary entry onto the stage of Rosetta's performance. ${ }^{8}$ Acutely aware of the dan-

6 Antonio Musumeci reads Ginia's decision to follow Amelia as an acceptance of the Pirandellian mask. He writes, "Amelia [...] ha accettato la maschera pirandelliana, e quella maschera è diventata il suo solo principio d'identificazione. L'osservazione finale di Ginia — 'conducimi tu' — con la fine della 'bella estate,' annuncia anche la sua accettazione della maschera, il suo rassegnarsi al recinto di una tipologia” (53). While Ginia's decision to follow Amelia involves an acceptance of the pirandellian recognition of multiple subjectivity, it does not necessarily involve a permanent closing off of options. Through Ginia has given up her dreams of finding her soul mate, her transgressive relationship with Amelia allows her to explore previously forbidden manifestations of desire and to redefine what it means to be a modern woman.

7 Though Thelma and Louise die in the eponymous 1991 film, these two women not only refuse to conform to society's ideas about what women should do and how they should act, but they also achieve feminine solidarity.

8 Clelia reflects on the significance of her different coats when she returns to her old neighborhood after many years. She writes, "Lasciando il parrucchiere non pensavo che al vecchio cortile, e rientrai in albergo, deposi la pelliccia, mi misi il 
ger of appearing in a role that contradicts her carefully composed and guarded identity, Clelia castigates herself for leaving her hotel room and making the silly ("sciocca") decision to enter into Rosetta's mis-en-scène. In the liminal space of the hallway, the narrative begins its process of tripping "up its narrator at every point, refusing to let her settle into anything approaching a definable, containable, identity" (Wood 104). Clelia finds herself drawn into a web of relationships that continually challenges her ability to maintain the self-sufficient and independent image of herself that she cultivates and projects.

Though Clelia ponders the cliché reasons a young girl might want to end her life-an unhappy romance, careless parenting, bad friendshipsClelia only begins to understand more about Rosetta and her unhappiness when she meets Momina, who is mentioned but not seen until she makes her dramatic entrance at the end of Chapter Seven, "Fu allora che arrivò Momina" (259). Clelia describes Momina's diva-worthy entrance, "Entrò con quell'aria malcontenta, da padrona, ch'era la sua. I suoi guanti valevano da soli tutto lo studio. La Nene, che le aprì l'uscio, sembrava la serva” (260). Clelia's use of Momina's gloves to quickly assess her social status reflects not only Clelia's specialized knowledge as a seamstress but also the importance of fashion in defining social status in postwar Italy. As Georg Simmel has observed, fashion not only communicates social standing, but it also puts up roadblocks for aspiring social climbers. A member of the most elite social class, Momina plays the part of the prima donna in the real life drama that mirrors Loris's failed attempts to stage a show; within the frame of the novel, real life is more dramatic than theatre. Though the diva's unusual name, Momina, is phonetically similar to mammina, she avoids appropriating maternal roles. Tra donne sole is not a novel that celebrates the "ritorno alle origini, alle Madri," as Giorgio Bárberi Squarotti has claimed (184). While this novel represents an attempt to return to the origin and to find a symbolic mother, Clelia's desire to revisit the people and places of her past is frustrated, and both Clelia and Momina choose not be become mothers. Either unable or unwilling to see past the surface of things, people and situations, Momina's myopia engenders a nihilism that infects first Rosetta and then Clelia. Momina is the antithesis of the stereotypical, self-sacrificing and life-giving mother.

Rich, cultured, and aristocratic, Momina does not produce anything

soprabito. Bisognava che tornassi in quella via della Basilica, e magari qualcuno poteva riconoscermi; non volevo avere l'aria superba" (239). 
useful for nature or culture. Her beaver fur coat and bare feet create a sterile, and sterilizing, hybridism. As Jacqueline Spaccini has pointed out in "Triste solitario y final" [sic], bare feet are an important symbol in Tra donne sole. Spaccini remarks:

Quella dei piedi non calzati, è una vera ossessione per la donna. [Clelia] non se le toglierebbe mai le scarpe davanti ad altri; a lei, lo stare senza scarpe, richiama un'immagine plebea: "arrivarono le casse; feci e rifeci una vetrina, senza scarpe ai piedi, come una commessa." Che lo faccia Momina, di continuo, appena può, le fa intravedere un nuovo mondo esattamente gli antipodi — di vivere la vita. In Momina il gesto è noncurante, di chi non osserva convenzioni, perché ne è al di sopra (140).

Though Spaccini's analysis of Momina's feet is perceptive, she misses the connection between bare feet and death because she does not cite the first time bare feet appear in the novel when Clelia sees Rosetta's lifeless body, "vestita da sera di tulle celeste, senza scarpe" (231-32). Bare feet, paired with an evening gown or a beaver fur coat, demonstrate an indifference that is incompatible with the appropriation of roles that create or preserve life.

While the women in Tra donne sole are imposing and beautiful, their desires are sterile and self-absorbed. Significantly, the only flowers that appear in Tra donne sole are daffodils or narcissi; the flowers Maurizio sends to Clelia at the novel's incipit foreshadow the narcissistic bent that characterizes love and desire in the narrative. While Momina was once Rosetta's lover and Momina, Clelia, and Beccuccio share a meaningless night of passion, these women—like Ginia and Amelia—do not use their sexual and social freedom to construct new channels for women to "give each other the gift of the 'self,' through the 'reciprocal gift of biographical 'life-giving' narratives" (Re 69). On the contrary, these women embellish, hide, and falsify their narratives that end with the death of the most fragile character.

When Clelia discovers that Rosetta has succeeded in killing herself, she turns against Momina to avoid questioning her role in Rosetta's tragedy. Clelia writes:

Le dissi che la colpa era sua; che, se anche Rosetta non si ammazzava, la colpa era sua. Le dissi non so che cosa. Mi pareva di avere ragione e di potermi vendicare. La insolentii come se fosse mia sorella (350).

Not only does Clelia demonstrate her desire to absolve herself of any responsibility for Rosetta's suicide, but her words also underscore the difficulty of establishing positive female relationships in patriarchal societies. 
Like a fairy tale heroine who mistreats her sister to secure the love of a man, Clelia distinguishes herself from Momina and uses her to deflect the guilt she feels for having been "sorda e cieca" to the messages Rosetta was broadcasting (350). ${ }^{9}$ Ultimately, Clelia must live with the knowledge that following "la sola regola eroica: essere soli soli soli" does not absolve her of responsibility and does not protect her from reciprocal constructions of identity that continually redefine how she appears to herself and to the world (MDV 10/15/1940).

Though Clelia and Pavese cling to visions of a "self that is," the texts examined above ultimately open up spaces for the destabilization of oppressive norms. While "Pensieri di Dina" and La bella estate both suggest how clothing, nudity, and interpersonal interactions continually refashion identity, all three texts represent modern women who refuse to allow biology and social conventions to define them. While these women enjoy significant economic freedom and are beholden neither to husbands nor to fathers, their sexual choices also point to their disregard for the restrictions patriarchal culture puts on the use of women's bodies. Dina pleasures herself instead of waiting for a man, and the women in La bella estate and Tra donne sole discover lesbian and bisexual desire. These women are neither defined nor contained by labels, and Pavese's representation of them helps to recast him as an author whose texts dramatize the schisms that exist within each modern individual and whose works embody the contradictions and conflicts that become apparent as a traditional, patriarchal world slowly yields to the challenges of modernity.

Assumption College, Worchester, MA

\section{WorKS CITED}

Bassanese, Flora. “Una donna: Autobiography as Exemplary Text.” Donna: Women in Italian Culture. Toronto: Dovehouse, 1989. 131-52.

Biasin, Gian-Paolo. The Smile of the Gods. Ithaca: Cornell University Press, 1968.

9 When speaking of rivalry between sisters, the evil stepsisters who lock Cinderella in the basement to increase their chances of marrying the prince come to mind. As Gilbert and Gubar have argued of Snow White, in patriarchal narratives, the king is always present. They write, "His surely, is the voice of the looking glass, the patriarchal voice of the judgment that rules the Queen's - and every woman's —self-evaluation" (38). By substituting his voice for the Queen's, his voice "resides his her own mirror, her own mind" (38). 
Butler, Judith. "Imitation and Gender Insubordination." Insidelout: Lesbian Theories, Gay Theories, Ed. Diana Fuss. New York: Routledge, 1991. 13-31.

De Beauvoir, Simone. The Second Sex. New York: Knopf, 1971.

De Grazia, Victoria. How Fascism Ruled Women: Italy 1922-1945. Berkeley: University of California Press, 1992.

Foucault, Michel. The History of Sexuality. Volume I: An Introduction. New York: Vintage Books, 1990.

Gibson, Francesca. "Pavese's Women." Onde di questo mare: Reconsidering Pavese. Ed. Rossella Riccobono and Doug Thompson. Leicester: Troubador, 2002. 71-80.

Gilbert, Sandra and Susan Gubar. The Madwoman in the Attic: The Woman Writer and the Ninteenth-Centry Literary Imagination. New Haven: Yale University, 1984.

Moretti, Franco. Il romanzo di formazione. Torino: Einaudi, 1999.

Musumeci, Antonio. L'impossibile ritorno. Ravenna: Longo, 1980.

Pavese, Cesare. Lavorare stanca. Torino: Einaudi, 2001.

—. Il mestiere di vivere. Torino: Einaudi, 2000.

—. La bella estate. Torino: Mondadori, 1999.

—. Tra donne sole in La bella estate. Torino: Mondadori, 1999. 227-351.

Re, Lucia. "Diotima's Dilemmas: Authorship, Authority, Authoritarianism." Italian Feminist Theory and Practice. Ed. Graziella Parati and Rebecca West. Madison: Rosemont Publishing and Printing Corp., 2002. 50-76.

Riccobono, Rossella. "Rappresentazioni di sé e l'affiorare di una coscienza di classe in La bella estate." Cesare Pavese: il mito, la donna e le due Americhe. Ed. Antonio Catalfamo. Santo Stefano Belbo: I Quaderni del CE.PA. M., 2003. 121-132.

—. "Vestirsi, svestirsi, travestirsi: arte e gioco della voce pavesiana." Vested voices II: Creating with Transvestism: from Bertolucci to Boccaccio. Ravenna: Longo Editore, 2007. 67-76.

Simmel, Georg. "Fashion." On Individuality and Social Forms. Chicago: University of Chicago Press, 1971. 294-323.

Spaccini, Jaqueline. "La pregnante vanità di Colei che non ha posto: Riflessioni sulle "poesie del disamore." Aveva il viso di pietra scolpita: cinque saggi sull'opera di Cesare Pavese. Roma: Arcane editrice, 2010. 45- 64.

. "Triste solitario y final: I rapporti conflittuali tra ceti sociali e sessi nello sguardo di Clelia Oitana." Cesare Pavese: il mito, la donna e le due Americhe. Ed. Antonio Catalfamo. Santo Stefano Belbo: I Quaderni del CE.PA. M., 2003. 133-44.

Squarotti, Giorgio Barberi. "Pavese o la fuga nella metafora." Sigma 1.3-4 (1964): 165-88.

Thelma and Louise. Dir. Ridley Scott. Metro-Goldwyn-Mayer, 1991.

Wood, Sharon. "Carnival and Masquerade in Cesare Pavese's Tra donne sole." Onde di questo mare: Reconsidering Pavese. Ed. Rossella Riccobono and Doug Thompson. Leicester: Troubador, 2002. 105-10. 
$-168-$ 